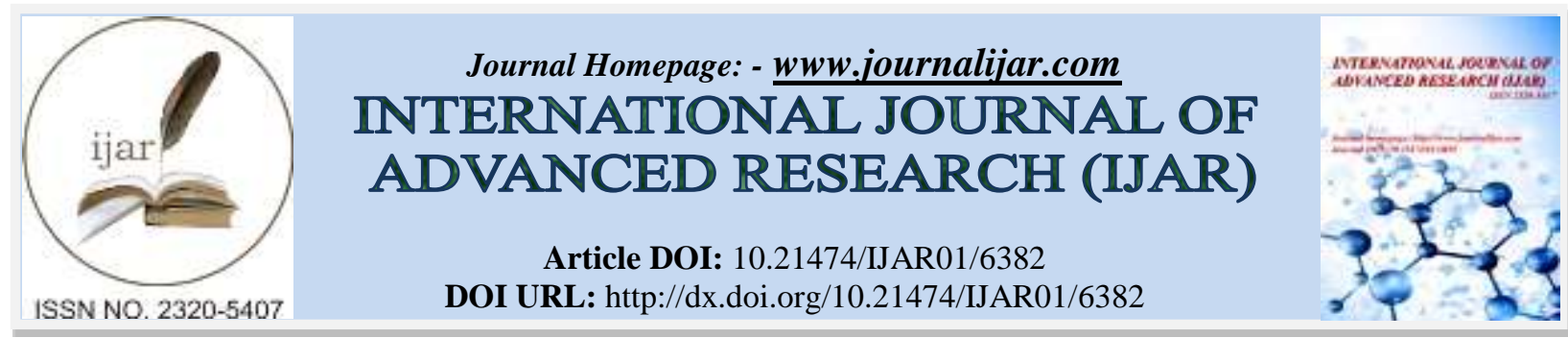

RESEARCH ARTICLE

\title{
CREATING CRITICAL THINKING FROM AFFECTIVE DOMAIN IN SUCCESSFUL LEARNING OF MATHEMATICS.
}

Kholidah Sitanggang, Herman Mawengkang and Tulus.

Faculty of Math and Science University of Sumatera Utara.

\section{Manuscript Info}

Manuscript History

Received: 22 November 2017

Final Accepted: 24 December 2017

Published: January 2018

Key words:-

Affective Domain, Mathematics,

Creative.

\begin{abstract}
The success of the learning process can be seen from the results of learning that is visible from the change in behavior on students, both the attitude and skills which are better than before. Mathematics learning success is not only determined by cognitive abilities but also affective abilities. Successful learning in terms of cognitive and psychomotor is affected by the affective condition of the students. Students who have interest in learning and a positive attitude toward learning will be pleased to learn, so it will achieve the maximum learning outcomes. Teachers should adjust teaching methods which consider students' affective conditions in order to make the student feel interested and motivated in learning mathematics. Some teaching methods that can enhance students' affective factors, that is: the model considerations, rational formation model (rational building model), clarification of the value (value clarification model). The more positive academic self-confidence of children, the higher motivation of the children to get an achievement. Children achievement is supported by the level of creativity in learning mathematics.
\end{abstract}

Copy Right, IJAR, 2018,. All rights reserved.

\section{Introduction:-}

A persistent problem in understanding the role of affect in mathematics teaching and learning has been to settle on a clear definition of what is affect or the affective domain (Gómez Chacón, 2000).

Learning mathematics is studying the concept, structure concept, and look for relationships between concepts and structures. Characteristic of this axiomatic deductive mathematics that should be known by the teachers so that they can learn the math properly, ranging from simple concepts to complex (Gagne, 1998)

The learning activities are activities that are the most central to the whole process of learning. This means that the success or failure of achievement in learning objectives depends on how the learning process was going on. The success of the learning process means the creation of good learning outcomes. The result of learning is the main benchmark to determine the success of student learning, which appears to be a transformation in term of students behaviour, it can be observed and measured by the changes in knowledge attitudes and skills. Such changes may imply an enhancement and a better development than before.

The success of mathematics learning is not only determined by cognitive abilities but also affective ability, which is very influential. Successful learning in term of cognitive and psychomotor is affected by students affective 
condition. Students who have interest in learning and a positive attitude toward learning will be happy to learn, so it can get the optimal learning outcomes. (Popham, 1995).

But in reality, education still found a problem which is the lack of the learning process. In learning process, children are less encouraged to develop creative, systematic and logical thinking skills. Teachers tend to give the knowledge that he had, stripping the children with a variety of ways such as: tell, teach, training them to complete an exercise, stating the facts, concerning with results rather than processes, praising the children when they answered question correctly and was angry with a vary ways when they answered it incorrectly, and teaching the material in the order page per page without discussing the links between concepts or problems. These treatments would hamper the creativity of students, whereas creativity is very important in learning mathematics.

Learning mathematics is a quite difficult challenge for students. Whether because of lack of motivation or desperation that makes students feel unable to solve mathematical problems. Students always assume that mathematics is a subject which is difficult, tedious, impractical, abstract and only clever people can do it. If that assesment have already been suggested then it will indirectly influence the affective student where the student interest in studying will be low, not motivated, can not create creativity in learning. Yet according Colomeischi (2014) common problems in learning mathematics is attitudes toward math and not lack of ability.

\section{Method:-}

In mathematics teachers should further adjust the teaching methods which is used by the student affective conditions, how to make students more interested, interested and motivated to learn mathematics. According to Nana Syaodih Sukmadinata (2005) some models of learning that can improve student learning affective, namely:

\section{Model consideration:-}

Model of learning in which students are encouraged to be more caring, more considerate to others, so that they can work together.

The assumptions of the model considerations are:

1. Moral behavior is the strengthening of self (self-reinforcing)

2. Moral education should be directed to the personality as a whole (the total personality)

3. Students who appreciate adults who made himself a "role model personality" (consideration)

4. Students are open to learning, but hate authoritarianism, domination

5. Teens gradually developed towards maturity in social relations.

\section{Steps of model consideration:-}

1. Provide a problem to the students

2. ask students to analyze the problems

3. each student is required to submit the results obtained, the other students have to respond

4. Discuss and determine the final answer together

Criteria For The Successful Application Of The Model Considerations Indicator Successful Application Of Learning Models Consideration Is:-

1. Rising student interest in learning math, judging by the seriousness and passion of students'

2. increased involvement of students, visits of student activity during discussions between students, students and teachers, question and answer between teachers and students.

3. Internalization which is seen from the changes in attitudes and behavior of students in class and in the school environment.

\section{Model of rational formation (rational building model):-}

Aiming to develop the maturity of thinking about values.

Steps Model of rational formation

1. Identify a problem together

2. Finding references from other books in terms of the completion of problem

3. Analyzing problems together

4. Finding the solution

5. Make decisions or final answer to the problem based on a book or a formula related. 


\section{Clarification value (value Clarification Model)}

Approach to teaching using inquiry or the process of assessing and helping students master the skills through learning.

\section{Steps value Clarification Model:-}

1. Students are free to choose the issues that has been provided by teachers.

2. Each student is expected to respect the choices of other students

3. Students have to work on that issue,

4. They have to present the result before the teacher.

In terms of self-confidence of students there is a strong correlation between the expected math test results of students and the students confidence about his abilities. From that relationship, it can be concluded that as follows:-

1. Students who feel "weak in mathematics" believes that success in math is a "coincidence or good luck".

2. If 'strong in math "students increasingly less believe that most of the contents of math is memorization.

3. If 'strong in math "students increasingly less believe that" success in the math test depends on the strength of the students memorize.

The way to improve the confidence of student in learning mathematics as follow:-

1. Inviting students to look at the advantages and disadvantages of self.

Teachers encourage students to concentrate on the positive things about themselves, give them reward for every positive thing possessed.

2. Invites students to try new things.

A new experience give the confidence and help students grow.

3. Using positive image

positive image is another way to build confidence, do not give room for the development of negative thoughts.

4. students improve their communication skills

5. Emphasizing the students to be themselves.

\section{Result:-}

There is a relationship between motivation and confidence that is the more positive academic self-confidence of children, the higher the achievement motivation owned subsidiaries, and conversely, the more negative academic self-confidence, the lower the wholly owned subsidiary of achievement motivation.

The learning achievement is a success in learning demonstrated by the achievement of high values. There is a positive influence creative thinking to mathematics achievement. Students who are high-level creative thinking will serve as an internal motivation that will support students to be more interested in learning mathematics. The elements that affect the creativity of the students are: motivation, intelligence, attention, interest and aptitude. Development of creativity can be done through the inquiry learning process and meaningful learning, where teachers create learning situations that may give a big opportunity to the students to solve problems, do some experiments, develop ideas or concepts by students themselves.

To foster the creativity of the students there are a few things to note that are: give motivation, stimulate students, give realistic expectations and guide the students. Teacher must also have techniques which can foster the creativity of students, namely:

1. Approach of "Inquiry" (finding knowledge). Teachers give a stimulus to students, provide the flexibility to argue, take initiative and act, provide support in finding knowledge.

2. Using connection advice techniques. Students were asked to express their ideas, then decide these ideas and determine which ideas that can be used in problem solving.

3. Giving an award for creative achievement. The award received will affect students in a positive self-concept, which will increase the confidence of students to act positively.

4. Enhance creative thinking through many mediums. Stimulants and sensitivity of students to the objects and the idea of presenting the material systematically arranged lessons with new ways, the use of audio-visual equipment. This approach increases the critical and creative thinking, and motivation and interest of students in group discussions. 
The learning achievement will be achieved to the maximum if the understanding of the concept are well ordered, so thinking creatively is a huge potential which have to be developed. Develop creative thinking ability is very important in the study of mathematics.

Therefore teachers should utilize existing technology in terms of stimulating the creativity of students. Teachers use props in learning and teaching process. Students who have high creativity will support the growing interest in learning, and it will encourage students affection in learning mathematics.

\section{Discussion:-}

The affective domain in mathematics learning. This research is about the low confidence of students in learning mathematics, self-doubt, too easily give up in learning and feel mathematics is a very difficult lesson.

The results of this study is there is a gender relation between students' attitudes and emotional reactions to mathematics learning, where men are more enthusiastic than women, emotional attitudes and reactions to mathematics affect their perceptions of discipline, self-concept of mathematics and the achievement of expectations, Student beliefs in terms of problem solving tend to influence positive or negative self-esteem about math. (Ignasia et al, 2006)

The Students Emotional Life and Their Attitude toward Mathematics Learning. This research about the emotions and negative attitudes of students that affect student performance in learning mathematics.

The results of this study are students' emotional intelligence in making different attitudes toward mathematics. The more emotionally intelligent of the students, the more motivated and positively oriented their math success. Attitude towards mathematics in terms of age: younger students are more anxious and less motivated for math than older students. (Colomeischi et al, 2014).

\section{Conclusion:-}

Students who have interest in learning and a positive attitude toward math will achieve maximum results. Some teaching methods can enhance students' affective factors, namely: the model considerations, rational formation model (rational building model), clarification of the value (value clarification model).

\section{Acknowledgments:-}

This is a thesis research, thanks to supervisors and related parties who have been concerned to provide input for the development of this research.

\section{References:-}

1. Colomeischi, Aurora Adina and Colomeischi, Tudor. 2014. The students Emotional Life and TheirAttitude toward Mathematics Learning. ScienceDirect, 180 (2015), 744-750.

2. Gagne, Robert M. 1998. Principle of Instructional Design. New York. Chigago Holt, Renart and Wisnton, Inc.

3. Gómez-Chacón, I.M. 2000. Matemática emocional. Los afectos en el aprendizaje matemático [Emotional mathematics. Affects in mathematics learning]. Madrid: Narcea.

4. Gomez-Chacon, I.M. 2011. Emotional Mathematics. Affects in Mathematics Learning. Madrid: Narcea.

5. Ignasia, NG, Nieto, LJB, Barona, E.G. 2006. The Affective Domain In Mahematics Learning. Internatioanl Electronic Journal of Mathematics Education, 1 (1), 16-32.

6. McLeod, D.B. 1992. Beliefs, Attitudes, and Emotions: New View of Affect in Mathematics Educations. In D.B. McLeod \& V.M. Adams(eds). Affect and Mathematical Problem Solving. Springer-Verlag (pp. 245-258)

7. Popham. W. J. 1995. Classroom Assesment, What Teachers Need to Know. Boston : Allyn and Bacon.

8. Sukmadinata, Nana Syaodih. 2005. Metode Penelitian Pendidikan. Bandung : PT Remaja Rosdakarya. 